\title{
HOW ARE THE RESULTS OF QUALITY ASSURANCE PROGRAMS USED TO INFORM PRACTICES AT A DISTANCE HIGHER EDUCATION?
}

\author{
Dr. Ojat DAROJAT \\ Faculty of Education \\ Universitas Terbuka \\ Jakarta, Indonesia
}

\begin{abstract}
This paper is to examine the implementation of quality assurance (QA) programs in distance higher education. Different challenges related to the development of QA programs at a distance higher institution and how to manage and implement the programs are discussed to show how the programs have been used to ensure the survival of the institution. A qualitative case study through semi structured interview and documentary analysis was employed to investigate the issue. The evidence indicates that the development and implementation of QA programs were very demanding and called for strong commitment of the top management and staff at all levels. Despite the challenges, the results of quality programs have generated significant benefits for the university through its regular self-assessment and stakeholders' feedback. The employment of the QA programs has called for different quality guidelines to maintain consistency in the management process and to ensure products and rendered services correspond with quality criteria. The results of this study might support sharing practical recommendations on how QA programs could be adapted in different distance higher institutions with different social and educational settings.
\end{abstract}

Keywords: Quality, quality assurance, distance higher education.

\section{INTRODUCTION}

Dale (2000) argued that the adoption of quality programs in education was partly derived from the marketization and privatization in higher education which have been encouraged within the discourses of neoliberalism in which economic policies with a focus on competition have supported the policy making framework in the public sector. Neoliberalism is a political movement which supports the ideological belief that competition, privatization and open market forces strengthen the economy (Shanahan, 2009). Within this ideological view, QA increasingly becomes defined in global markets, including in education to create transparency, to ensure quality, and to inform different stakeholders (Martin \& Stella, 2007). According to Gibson (1986), however, quality in the higher education context is "notoriously elusive of prescription and no easier even to describe and discuss than to deliver in practice" (pp. 128-129). Martin and Stella (2007) argued that the dilemma of defining quality in higher education "is not merely a question of setting standards; it is also an issue of who defines it on the basis of what interest" (p. 33). For this reason, conceptualizing quality in higher education in general, and distance higher education (DHE) in particular, may serve multiple perspectives. Harvey and Green (1993) argued that 'quality', like 'liberty' or 'equality', is a slippery concept. 
While QA policies have gained pre-eminence in manufacturing sectors, in higher education, not all people agree universally with the adoption of QA policies. The importation of QA programs from the world of business into higher education tends to inhibit innovation in instructional process rather than advance it (Nicholson, 2011). Some argue that a common criticism of QA programs is that this focus on QA pays little attention to educational processes and theories; as a result, quality improvement is only incidental (Bogue, 1998; Harvey \& Knight, 1996). Plimmer, Clarke-Okah, Donovan, and Russell (2012) noted that the adoption of the concept of quality into education institutions as the conversion of education institutions to the manufacturing industries encourages "mechanistic compliance-driven behaviors" ( $p$. 165). According to Ryan and Brown (2012), the objections to the emerging QA issues in distance education reference what many academics perceive as "an ideology which sought to reduce academic autonomy, and teaching to an atomized, mechanistic assembly line of resources (p. 92).

Along with the problematic nature of introducing quality in higher education, the perspectives of QA have also been identified with no universal definition. The concept and practice of QA has also been used very loosely with other related terms such as quality control, quality assessment, quality audit and accreditation (Martin \& Stella, 2007) with no general consensus on the exact meaning of each. Some note that QA refers to "those mechanism and procedures designed to reassure the various stakeholders in higher education that institutions accord a high priority to implementing policies designed to maintain and enhance institutional effectiveness" (p. 178). Vlasceanu, Grunberg, and Parlea (2007) argue:

Quality Assurance: An all-embracing term referring to an ongoing, continuous process of evaluating... the quality of a higher education system, institutions, or programs. As a regulatory mechanism, quality assurance focuses on both accountability and improvement, providing information and judgments (not ranking) through an agreed upon and consistent process and well-established criteria. Many systems make a distinction between internal quality assurance (i.e. intrainstitutional practices in view of monitoring and improving the quality of higher education) and external quality assurance (i.e. inter- or supra-institutional schemes assuring the quality of higher education institutions and programs). (p. 74)

For Vlasceanu, Grunberg, and Parlea (2007), QA in higher education requires a dynamic process involving internal approaches to the institution and some also external agencies. It is a never ending process for "maintaining and improving quality rather than simply a system of evaluation and checking for errors" (Warren, McManus, \& Nnazor, 1994). QA in higher education also involves a systematic and integrative management procedures employed to assure quality (Harvey \& Green, 1993; Sallis, 2002; Jung 2004; Jung \& Latchem, 2007).

Despite the difficulty in conceptualizing the term quality and $Q A$, there is a growing commitment among distance higher education to adopt QA programs (Belawati \& Zuhairi, 2007; Jung \& Latchem, 2007). Jung (2004) and Martin and Stella (2007) disclose that a number of different institutions, such as Asian Association of Open University (AAOU) (2010) and Commonwealth of Learning (COL) (2009), have designed principles and guidelines how to assure quality in distance education. According to AAOU (2009), QA has become strategic issues for DHE in response to accreditation and accountability, competition, and economic reasons. 
This paper will discuss a specific issue on how QA programs in a DHE have been implemented for accreditation, accountability, and continuous improvement. Universitas Terbuka (UT) Indonesia has been selected for this study. UT is the state university which has been designed by the Indonesian government to provide services for qualified higher education, especially for those which for some reasons cannot join conventional higher education. UT has been selected for the reason that the University has employed internal quality assurance system and voluntarily also invited external quality bodies including Indonesian Accreditation Board for Higher Education, ISO agencies, and International Council for Open and Distance Education (ICDE). The discussion begins with the overview of the university that provides general umbrella and a contextual background for the whole discussion. Further, the discussion elaborates some important issues related to research methodology and findings by addressing some significant themes relating to the implementation and how the results of QA programs have been used to inform current practices at the university. Finally, the discussion will present implications of how will other DHE universities may adapt and share the practices with different social and educational settings.

\section{Universitas Terbuka, Indonesia}

In 2017, Universitas Terbuka (UT) will be 33 years of age. For three decades, UT has employed the mandate to serve people, either the ones living in Indonesia or overseas. Following the development and the achievement of the university, since 2001 UT has made itself a worldclass distance education institution to produce graduates with high competitiveness and to develop theories and practices in distance education. Currently, UT is one of the 'mega universities' in the world (Daniel, 1996) with a student body of over 300,000 as of 2015 (UT, 2016). As part of its commitment to promoting quality education, UT has initiated and implemented a QA system for more than ten years. The university has adopted the AAOU QA framework encompassing various key areas of the distance education system. In 2001, strategic action was carried out through the establishment of a QA system committee. A further organizational change has also been taken through formally establishing the Quality Assurance Centre with its strategic role to manage the development and implementation of the QA program (Belawati \& Zuhairi, 2007). UT has been awarded the international certificate of quality by ICDE since 2005 and International Organization for Standardization - ISO 9001 since 2006. In addition, all study programs at UT have also been accredited by the National Accreditation Board for Higher Education of Indonesia.

\section{PURPOSE}

The overall purpose of this study is to explore and understand the issues relating to the implementation of QA programs and how the results of QA programs have been used to inform practices in a distance higher education. It is hoped that the qualitative nature of the study can address the specific approaches and methods in employing QA programs especially with regard to the open and distance learning.

\section{METHODOLOGY}

This present study adopted the epistemology of constructionists' views who claim that meaning is not discovered but constructed. The QA programs in DHE specifically at UT, is social phenomenon that is socially constructed by the people who participated in it. Following the Crotty's model (1998), the constructionism epistemological approach helped the researchers to understand how QA programs have been socially and collectively constructed by the people at UT. Constructivist epistemological view helped the researchers to explore how the context of QA programs and the placement of the programs within wider social environments has impacted on constructed understandings. In this study, the researchers employed case study 
research (Stake, 2005) as it attempted to understand phenomena in the social world. As UT is social institution, qualitative case study is more appropriate in order to better understand the dynamic of human aspects behind the QA programs.

In the present research, semi-structured interviewing technique or "general interview guide approach" (Patton, 1990, p. 280) was used for more practical approach. Identified participants were interviewed using prepared interview guides to obtain information, but the researcher had flexibility to pursue further questions relevant to the purpose of the research and to gain important information. In addition, to support this study, documentary analysis had also been employed. The researchers collected and analyzed the QA documents at research site, such as minutes of meetings, institutional publications, review reports, evaluation reports, newsletters, standards and operational procedures of QA model. These documents had been used to describe specific conditions and practices, spot trends, as well as document the historical and current development of QA programs.

In order to more fully understand QA programs at the research site and maximize the information about the implementation of the programs, the researchers sought participants who would likely provide typical and divergent data. Thus, the most appropriate sampling strategy to support the present study was purposive (Lincoln \& Guba, 1985; Erlandson, Harris, Skipper, \& Allen, 1993) or purposeful (Patton, 1980).

There were six key informants involved in this research. The key informants came from QA actors at the university included:

$>\quad$ The head of the Quality Assurance Center - 1 participant

$>$ Policy contributor (Vice Rector) - 1 participant

$>$ The head of Faculty or Department -1 participant

$>$ The head of regional/learning center -1 participant

$>$ Tutor or teaching provider -1 participant

$>$ Administration staff -1 participant

The six key informants who were involved in initiating, developing, and implementing QA programs were asked about their insights regarding the development and implementation of QA programs. They were also asked about the results of their current QA programs to support quality improvement. Moreover, interviewees were also invited to offer their insights on the problems of using QA programs and on how the results of the QA programs have been utilized for continuous improvement. For the reasons of ethical consideration, a research approval from the university and informed consent from selected key participants were gained before the research.

Further, thematic analysis was employed to present and discuss the findings drawn from content analysis of interview transcripts and documents. Analysis of transcribed interviews and documents were coded after the data collection. Transcribed interviews supported by official documents generated a number of emerging themes through the use of two cycles of coding methods. In the first cycle, we used structural coding (Saldana, 2009). In the second cycle of coding, an axial coding method was used to strategically reassemble data for the purpose of categorization (Saldana, 2009). Coding, categorizing, and themes were arrived at through content analysis of transcribed interviews involving iterative reading, identifying initial concepts, developing codes representing evocative attribute for recurrent concepts, categorizing related codes, developing and grouping conceptual constructs or themes (Saldana, 2009). In this analytical work, the list of codes represented the comments and served as symbolically linking from the data to the research questions. For the purpose of the 
study, the identification of codes, categories, and emerging themes was supported by MAQXDA 10 application software.

Different limitations were present in this study. Firstly, this qualitative research relied on interview results. Therefore, language has been regarded as critical factor that might be have significant impact on the construction of meaning. To address this issue, "respondent validation method" (Silverman, 1994) has been used to check data and interpretations. Secondly, this research has been designed to explore on how QA programs have been adopted to promote continues improvement in particular distance education institution and in the context of Indonesia's educational landscape. Therefore, generalizations could not be drawn an inappropriate based on this study (Denzin, 1983).

\section{PRESENTATION OF THE RESULTS}

This session explores critical issues relating to the implementation and how the results of QA programs have been used to inform current practices at UT Indonesia. Based on thematic analysis then the consolidated major themes from categorization, combining emergent themes are presented in the following table.

Table 1. List of the themes related to the research question

\begin{tabular}{lll}
\hline Research question & \multicolumn{1}{c}{ List of themes } \\
\hline $\begin{array}{l}\text { How are the results } \\
\text { of QA programs used } \\
\text { to inform practices at } \\
\text { a distance higher } \\
\text { education? }\end{array}$ & Theme 1 & $\begin{array}{l}\text { The adoption of QA programs called for QA } \\
\text { manuals served as the guide for } \\
\text { implementation }\end{array}$ \\
\hline Theme 2 & $\begin{array}{l}\text { Continuous quality assessment is done } \\
\text { through self-evaluation } \\
\text { Continuous improvements have been } \\
\text { taken based on internal and external } \\
\text { quality assessment } \\
\text { QA is perceived as being too demanding } \\
\text { and time consuming }\end{array}$ \\
\hline
\end{tabular}

Four interesting issues relating to how the results of QA programs at UT have been used to inform practices were captured through the diverse responses from different key informants supported by documentary analysis. The following discussion elaborately presents these four emergent themes.

Theme 1: The Adoption of QA Programs Called for QA Manuals Served as the Guide for Implementation

UT has had formal quality manuals that served as the guide for implementation. Quality manuals have been regarded as the first document level in the hierarchy of the quality management system documentation system. Quality manuals also contained policies related to quality processes involved for university operations. Therefore, quality manuals were official documents covering all important aspects of the University QA system.

The employment of the QA system has been translated into 10 components of quality areas within the University quality assurance framework and integrated into what they call 'Sistem Jaminan Kualitas Universitas Terbuka' (UT, 2012) shortened to 'Simintas-UT.' The SimintasUT has been regarded as the University' guidelines for continual improvement in 
implementing quality. These quality manuals have been equipped with 110 statements of best practices as quality policies (see the following table).

Table 2. UT'S QA POLICY MANUALS

\begin{tabular}{|c|c|c|}
\hline No. & Area of Quality & $\begin{array}{l}\text { Statement of Best } \\
\text { Practices (SOBP) }\end{array}$ \\
\hline 1 & Policy and planning & 7 SOBP \\
\hline 2 & $\begin{array}{l}\text { Human resource recruitment and } \\
\text { development }\end{array}$ & 9 SOBP \\
\hline 3 & Management and administration & 21 SOBP \\
\hline 4 & Learners & 10 SOBP \\
\hline 5 & Program design and development & 6 SOBP \\
\hline 6 & Course design and development & 14 SOBP \\
\hline 7 & Learning supports & 18 SOBP \\
\hline 8 & Assessment of student learning & 15 SOBP \\
\hline 9 & Media for learning & 7 SOBP \\
\hline 10 & Research and community services & 13 SOBP \\
\hline
\end{tabular}

These components of quality areas were based on the idea that reflected the needs of the university as a distance teaching university. According to one of the interview subjects, it was decided these QA quality areas were adopted from AAOU QA framework (UT-QC-02). For the implementation purpose, these 10 components were elaborated further into different quality criteria or statements of best practices.

Another crucial aspect of the university quality manuals was that it provided different quality procedures for all QA areas. System operating procedures (SOPs) highlighted steps by steps activities in the implementation of QA that should be regarded as the highest reference documents for the procedure manual for each department throughout the university. Belawati, Zuhairi, and Wardani (2012) addressed the importance of a quality manual as the guide in QA implementation as follows:

The QA Policy Manual ... explained the job descriptions and performance standards/ criteria, how feedback would be provided, the appeals process and how various incentive systems related to performance. It was found that these not only helped staff in performing their daily tasks, but also triggered the realization that their knowledge and skills could always be improved upon and that targets and performance indicators could always be raised. ( $p$. 116)

This study also confirmed that the employment of quality manuals at UT required work instructions for different actions to develop, maintain, and change desired appropriate work culture to support the implementation of the university's QA programs.

Theme 2: Continuous Quality Assessment is done through Self-Evaluation

Since the adoption of QA programs in 2002, the university has employed continuous selfevaluation as part of their QA programs. Quality assessment of the learner support services for example and priority setting for improvement were conducted both unit-by-unit and university-wide. Self-assessment programs have been regularly conducted at UT's head office and its regional renters scattered all the country involving qualified internal quality auditors. The coverage of self-assessment includes different areas for example registration and admission services, learning materials and learner support services (face-to-face tutorials, 
practical work), examination process, marketing, publication, and cooperation, and other internal management issues such as human resources and infrastructure. As an example, the results of internal self-assessment in the first semester 2015 at 14 Regional Offices are illustrated in the following diagram.

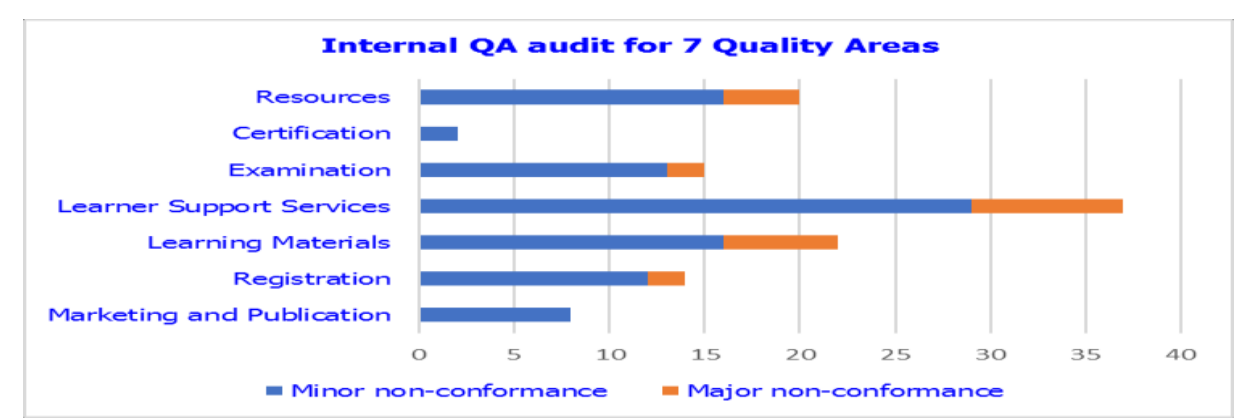

Figure 1. Quality Audit Findings by Quality Areas in 2015 in the Group of 14 Regional Offices Source: Quality Assurance Center (2015)

The above diagram disclosed that the results of internal quality audit have been divided into two categories, minor and major non-conformance. Considering the non-conformance, it was necessary for the management to do analysis and it was expected that the management will get a more comprehensive description about the on-going implementation of UT's internal quality assurance system and identifying preventive actions needed for improvement.

Managers in relevant departments at UT' s head office as well as every director of $\mathbf{4 0}$ regional offices were required to conduct quality assessment using the university's quality framework as instruments. One respondent noted that:

Internal quality assessment is part of our program. We invite all departments and different team at the faculty level to present and discuss their findings and problems they face.... In this management review meeting, we identify various strategies necessarily for future improvement. (UT-FD-04)

Another respondent recounted the implementation of quality assessment as follows:

We conduct self-evaluation every six months by referring to quality standards set by the UT's head office. Based on the results of these measurements, we know our weaknesses and strengths in achieving our criteria. We will discuss these findings [non conformities] in our management review meeting. We will take corrective action based on our previous weaknesses. (UT-LC-06)

The QA system was a cycle of continual improvement needing regular monitoring and evaluation. One respondent mentioned that quality assessment was conducted every month in order to examine and update the status of every student's complaints and inquiries (UTCS-05). A different respondent recounted that monitoring and different levels of management have performed evaluation programs regularly. The results of the evaluation were important information for management review meetings at the unit and national levels (UT-QC-02) 
Theme 3: Continuous Improvements have been Taken Based on Internal and External Quality Assessment

Internal and external quality assessment generated positive feedback for UT in its efforts to improve UT's systems in different quality areas. Supported by the results of quality assessment, various actions in ten quality areas were taken for continual quality improvement, such as revising QA policies, SOPs, works instructions, and quality criteria (UTFD-05), revising printed learning materials, and developing an online application as a new channel for support services (UT-QC-02). Based on the interview data supported by published and unpublished documents, a number of actions to support continual improvement have been identified and discussed below.

$>$ Developing QA manuals-UT have developed a set of QA manuals equipped by quality procedures to guide the implementation of QA. The QA manuals emphasized the interrelationship among processes.

$>$ Establishing QA center-the university has been equipped by the office totally dedicated for managing the implementation of QA within the university. The QA center was a strategic player for the university for planning and coordinating among departments within university and external QA agencies.

$>$ Developing and reviewing the institutions' policies-As the university's internal and external environment and demands were in constant change, the university developed and reviewed new policies and existing strategies that supported the implementation of QA that fitted the new trend of distance education.

$>$ Developing Learning Materials for Students with Disability (Students without Sight) - In line with the system of open learning it applies, it is possible for UT to accept students with disability. For example, before 2010, UT did not have facility for blind students. Currently, UT has provided services blind students in the form audio learning materials. With this kind of materials, students have options to choose the materials to learn. At the moment, UT has audio learning materials available for blind students only at S1 Program of Communication. The effort to provide learning materials for students with disability will continue in the years to come in order to improve access for wider audience. (UT, 2015)

$>$ Conducting training for selected staff to become internal QA auditors/ assessorsthe university has trained their selected academic and administrative staff across departments in order to facilitate internal quality assessment. At UT all internal QA auditors have been certified by ISO 9001 training agencies.

The current processes of QA used to inform practice in learner support areas, for example, was revealed by one participant as follows:

\begin{abstract}
QA has greatly helped us in improving quality of our learning support services. For example, as we know that $Q A$ requires records or documents that underlay all activities. Before the implementation of the QA system, we do not have documents regarding tutors' activities when they are involved in tutorial classes. Tutors often make mistakes in writing students' names and students' ID numbers. Sometimes, tutors also make a mistake in using a formula for calculating students'scores. Now, through the implementation of QA, all these weaknesses are greatly reduced. (UT-LC-06)
\end{abstract}

The recommendations from the external quality auditors, specifically the ICDE quality reviewers in $\mathbf{2 0 1 0}$ and 2015, have also encouraged to UT to take various actions as follows: 
Customer relationship management (CRM) application. Online CRM has been developed in order to improve support services efficiently and effectively. Through this service, students can easily send their inquiries, compliments, and complaints and receive responses in a timely manner. (UT, 2010, pp. xi - xiii)

Increasing the Use of Digital Library, Learning Resources Centers (LRCs) at the ROs, and Local Libraries - Rapid advanced technology has changed the paradigm of study and learning. Consequent/y, UT needs to provide wider access for students to make use of various learning resources. To improve learner support services, especially those related to access to learning resources and library, UT has develop a digital library. The program was especially designed for students who have access to internet connection. Through digital library, students can access course materials for the courses they take. In addition to that, this program also enables students to get electronic journals (e-journals) from several publishers, electronic books (ebooks), and other scientific works such as thesis. (UT, 2015, p. XXV)

The implementation of the current QA system has also inspired UT to address future plans for digitising all learning materials as a response to the global movement for the use of Open Educational Resources (OER). As the university grew, UT's QA system provided a platform for UT in developing the quality of education in line with its mission to provide and widen access to higher education for all economic levels of society, with different ethnic groups and regional cultures.

In addition, faculty also received different inputs with regard to the quality of learning support services from students and instructors. According to the Vice Dean for Student Affairs "the learning services for PKP [Professional Development Program for elementary teachers] is currently in the process of improvement based on the inputs from students and the Directors UT' Regional Offices (UT-FD-03). Currently, UT also employed new teaching delivery, Webminar, for virtual classroom, to respond to students' demand (UT-QC-02).

Theme 4: QA is Perceived as Being Too Demanding and Time Consuming

Most of respondents expressed that managing a QA system for a large part of the student body and complex distance teaching institution was absolutely demanding. Besides, involving three external quality standards (Indonesian Accreditation Board for Higher Education, ISO 9001: 2008, and International Council for Open and Distance Education) is very demanding for documentation activities. One of the respondents frankly admitted:

The main challenge in implementing quality program ... is documentation. We have to spend a lot time handling documentation. At the beginning, the external quality auditor focuses on the existence of documents that support relevant activities... Now, auditors not only examine the existence of these documents but also assess the validity of these documents. We in the regional office find it very difficult to check the validity of the content for all documents due to the limitations of human resources ... there are many documents to be maintained. (UT-LC-06)

Since 2010, the university faced a serious challenge in terms of how to maintain compliance to different external quality standards with different focuses and integrating these various standards into internal mechanism. One respondent highlighted that the university has tried 
to integrate the quality criteria required by BAN-PT [National Accreditation Board for Higher Education], ICDE, and ISO (UT-QC-02).

The foregoing discussion has laid down evidence that QA has been regarded as a pivotal component for continual improvement and how the results of QA programs have been used for current practices at the university involved in this study. The next section will focus on discussion and conclusion of this research.

\section{DISCUSSION}

It was disclosed that the adoption of QA programs at the university has been supplemented by different quality guidelines. The university has developed different general quality guidelines to implement its QA policies, including employing standard operating procedures (SOPs) and work instructions for carrying out QA programs in different quality areas. These SOPs cover all information on how specific quality areas must be implemented. The use of SOPs may benefit the university by for example maintaining the consistency of the management processes. However, there is a debate surrounding the practice of SOPs that may also risk the universities' rigorous quality systems in terms of teaching and learning provisions. It is argued that quality guidelines provide clear processes to be consistently implemented to ensure the achievement of expected outcomes. However, this current practice will lead universities to disempowered faculty and tutors in academic autonomy, and hamper the encouragement of innovative instruction. As it is highlighted by Ryan and Brown (2012) that the emergence of QA programs in distance education reference has been regarded as "an ideology which sought to reduce academic autonomy, and teaching to an atomized, mechanistic assembly line of resources (p. 92).

With regard to this problematic nature of adopting SOPs in DTUs, this study disclosed that there is no specific evidence being reported that the use of SOPs hampered and disempowered faculty in their innovative teaching and academic autonomy. While faculty report that QA is time consuming and demanding, they appear to maintain innovative teaching and academic autonomy. In line with the implementation of their quality program, faculty member support rigorous interaction through different activities in the class such as inviting students' opinion relating to their working experience, creating discussion forum dealing with students' problems in learning, and managing online learning forum to enhance interaction and communication (UT-AS-03).

The university has deeply involved in conducting internal and external quality audits to assess its current QA practices. The current QA processes at the university have been used to inform practices in different QA areas to ensure that the university continuously transforms itself and perform better. The university employed two major quality audits: self-assessment (internal quality audit) and external quality audits to facilitate continuous quality improvement. The university conducted quality self-assessments; it carried out regular internal quality audit through different forms of monitoring, evaluation programs, and management review meetings. With regard to the internal mechanisms for quality self-assessment, Harvey and Green (1993) believed that QA is not about "specifying the standards or specifications against which to measure or control quality. [QA] is about ensuring that there are mechanisms, procedures and processes in place to ensure that the desired quality ... is delivered" (p. 20). For the purpose of the self-assessment programs, UT adopted and contextualized the QA model established by AAOU. In order to validate its internal quality audits, the university has involved external QA professional agencies as part of its QA programs. Additionally, UT has also voluntarily invited ICDE to assess its universal standard in practicing distance education 
systems covering 10 quality areas. The adoption of quality frameworks from AAOU, ISO, and ICDE can be regarded as an exemplar of the implementation of QA agendas in the university. Recognizing that the employment of self-assessment for QA program, Sallis (2002) argued that self-study is an excellent first diagnostic step on the path to quality. Sallis (2002) further stated that "...self-assessment process allows the organization to discern clearly its strengths and areas in which improvements can be made..." (p. 148). Besides the involvement of National Accreditation Board of Indonesia for Higher Education (BAN-PT), the university also voluntarily invited International Council for Open and Distance Education (ICDE)'s quality review since 2005 and ISO 9001 agencies. Inspired by its vision to become one of the world's leading DHE, one of the respondents mentioned as follows.

ICDE has its own criteria that are different from quality standards requested
by BAN-PT and not necessarily exactly the same as our quality assurance
system... [ICDE] gives a list of questions that we have to answer in a
portfolio. From the list of questions, we will know what the ICDE concerns in
assessing quality. When ICDE conducted a quality review, they also
examined what actions were taken following their previous
recommendations five years ago. (UT-QC-02)

In one side, the decision to invite three external QA agencies (BAN PT, ISO 9001 agencies, and ICDE) has been perceived as an important method by management for assuring quality of study programs, internal management, and practicing international quality criteria for distance higher education. On the other side, however, the implementation of self-assessment and three external quality audits generate burdensome of documentations and other administrative works for staff and particularly faculty (UT-LC-06), it seems important for the university to map out and get more resources to implement $Q A$ programs. It seems very important as this study further disclosed that the adoption of QA programs presents additional challenges for staff and management.

The implementation of QA involving internal and external quality auditors has been perceived as being too demanding. The QA application generates additional worked for academic and administrative staff particularly in terms of documentation activities. Developing and reviewing QA manuals, including QA policies and quality guidelines, continuous monitoring and evaluation to ensure QA implementation are among other activities that must be carried out. Top managers, academic and administrative staff involved in this study confirmed and shared similarities that the implementation of QA in different quality areas requires strong commitment, effort, and active participation from all staff and top managers. It was reported by some respondents that quality was responsibility of everyone; all staff must undertake their roles responsibly and contribute to the QA processes.

The implementation of the current QA system has also inspired UT to address its future development for digitizing all learning materials as a response to the global movement for the use of Open Educational Resources (OER) and Massive open and online courses (MOOCs). As the university grew, UT's QA system provided a platform for UT in developing the quality of education in line with its mission to provide and widen access to higher education for all economic level of society with different ethnic groups and regional cultures.

\section{CONCLUSION}

From the forgoing discussion and findings, it is clear that to survive and prosper, UT has employed QA programs in different quality areas. The university has employed their quality criteria to comply with the three external quality standards. The university has involved BAN- 
PT, representing the Indonesian government, and has voluntarily invited ISO certification agencies and ICDE to assess the following three different areas of focus: educational programs, management processes, and the standardized practices of open and distance education.

The university has had a formal quality management system, known as Simintas UT since 2003, adapted and contextualized from the AAOU's QA framework. AAOU's Quality framework has been regarded as a leading model for the university self-assessment and shared by all staff at UT head office and regional centers. These quality guidelines clearly explain quality criteria for different quality areas. Along with the use of the quality manuals, the university has used the results of quality audit to inform its current practices through different strategies including the development of QA manuals. UT's quality manuals also constitute the university's QA policies that must be regarded as a major reference for all units or departments in developing internal mechanism and implementing quality. With regard to the implementation of QA in different quality areas, it was found that the application of QA has been supported by the development of SOPs equipped by their work instructions.

Another theme also emerges when dealing with the challenges of QA process and how the results of QA programs have been used to inform practices. The implementation of QA programs has been perceived as too demanding and time consuming in terms of documentation activities. To ensure the benefits from implementing QA, the university is periodically involved in self-assessment and external quality audits as an important step to be taken for identifying various actions that must be pursued to ensure quality improvement. Although the present study is limited to the Indonesia's educational setting and interpretative qualitative paradigm in nature, it is hoped the findings provide some understandings on how QA programs have been implemented at the distance higher education. The findings of the study may assist the DHE institutions in developing QA system that meets with local needs and international standards. Further, the results of the study may also illuminate some of the philosophical and practical issues regarding QA programs and how to use the results of the QA program to inform its current practices. As quality has always been regarded as a strategic issue in distance education, the results of this research is substance enough to be shared with others about some key characteristics, problems, and benefits of adopting the QA programs at the Universitas Terbuka, Indonesia.

\section{BIODATA and CONTACT ADDRESSES of AUTHOR}

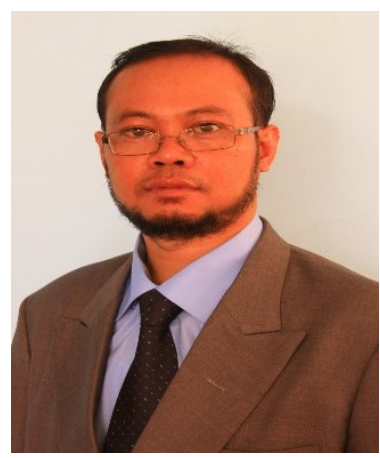

Dr. Ojat DAROJAT is a Professor at Faculty of Education Universitas Terbuka (UT) Jakarta Indonesia who has more than twenty seven years of experience working for distance teaching university. Currently he has been assigned as the rector of UT Indonesia. His main area of research interest is curriculum and quality assurance system for distance higher education. He has over than 15 articles published in national and international journals and 1 international book chapter and other national and international papers submitted to the international conference. Since 2017 , he has been assigned as the ICDE's focal point people for the Quality Assurance Network for Asian region.

\section{Dr. Ojat DAROJAT}

Social Studies Department, Faculty of Education

Universitas Terbuka, Jakarta, Indonesia

Phone: +62-21-7490941 / 2014

Mobile: +62-81281393444

E-mail: ojat@ecampus.ut.ac.id 


\section{REFERENCES}

AAOU (2009). A framework for developing a quality assurance system within a dedicated distance education institution. Unpublished. Jakarta, ID: Universitas Terbuka.

AAOU (2010). Quality assurance framework. Retrieved January 17, 2011 from http://www.aaou.net

Belawati, T. \& Zuhairi, A. (2007). The practice of a quality assurance system in open and distance learning: A case study at Universitas Terbuka Indonesia (The Indonesia Open University). International Review of Research in Open and Distance Learning, 8(1), 1-15.

Belawati, T., Zuhairi, A., \& Wardani, I. G. A. K. (2012). Quality assurance in a megauniversity: Universitas Terbuka. In I. S. Jung \& C. Latchem (Eds.), Quality assurance and accreditation in distance education and e-learning: Models, policies, and research, (pp. 113-123). New York: Routledge.

Bogue, E. G. (1998). Quality assurance in higher education: The evolution of systems and design ideals. In G. H. Gaither (Ed.), Quality assurance in higher education: An international perspective, (pp. 7-18). San Francisco: Jossey-Bass Publishers.

COL (2009). Quality assurance toolkit for distance higher education institutions and programmes. Vancouver, BC: The Commonwealth of Learning.

Crotty, M. (1998). The foundation of social research: Meaning and perspective in the research process. London: Sage Publications.

Dale, R. (2000). Globalization: A new world for comparative education? In J. Schriewer (Ed.), Discourse formation in comparative education, (pp. 87-110). New York: Peter Lang.

Daniel, J. S. (1996). Mega-universities and knowledge media: Technology strategies for higher education. London: Kogan Page.

Denzin, N. K. (1983). Interpretive interactionism. In G. Morgan (Ed.), Beyond method: Strategies for social research, (pp. 128-146). Beverly Hills, CA: Sage.

Erlandson, D. A., Harris, E. L., Skipper, B. L., \& Allen, S. D. (1993). Naturalistic inquiry: A guide to methods. Newbury Park: Sage Publications.

Gibson, A. (1986). Inspecting education. In G. Moodie (Ed.), Standards and criteria in higher education, (pp. 128-135). Guildford, Surrey: SRHE \& NFER-Nelson.

Harvey, L. \& Green, D. (1993). Defining quality. Assessment and Evaluation in Higher Education, 18(1), 9-34.

Harvey, L. \& Knight, P. (1996). Transforming higher education. Buckingham, UK: Open University Press and Society for Research into Higher Education.

Jung, I. S. (2004). Quality assurance systems in mega-universities and selected distance teaching institutions. A paper presented at the Second Global Forum on International Quality Assurance, Accreditation and the Recognition of Qualifications for Widening Access to Quality Higher Education, UNESCO, Paris, France, June 2829, 2004. Retrieved July 26, 2011 from http://portal.unesco.org/education/en/ev.php-URLID=31915\&URL_ DO=DOTOPIC \&URLSECTION=201.html.

Jung, I. S. \& Latchem, C. (2007). Assuring quality in Asian open and distance learning. Open Learning, 22(3), 235-250. 
Lincoln Y. S. \& Guba, E. G. (1985). Naturalistic inquiry. Newbury Park, CA: Sage Publications.

Martin, M. \& Stella, A. (2007). External quality assurance in higher education: Making choices. 7 place de Fontenoy, Paris: UNESCO.

Nicholson, K. (2011). Quality assurance in higher education: A review of the literature. Retrieved March 17, 2012 from http://cll.mcmaster.ca/COU/pdf/Quality\% 20Assurance\%20Literature\%20Review.pdf?referer=http \%3A\%2F\%2Fworks.bepr ess.com\%2Fkaren_nicholson\%2F19\%2F.

Patton, M. Q. (1980). Qualitative research methods. Beverly Hills: Sage Publications.

Patton, M. Q. (1990). Qualitative evaluation and research methods. Newbury Park, CA: Sage.

Plimmer, G., Clarke-Okah, W., Donovan, C., and Russell, W. (2012). Lowering the cost and increasing the effectiveness of quality assurance: COL RIM. In I. S. Jung \& C. Latchem (Eds.), Quality assurance and accreditation in distance education and elearning: Models, policies, and research, (pp. 162-172). New York: Routledge.

Ryan, Y. \& Brown, M. (2012). Quality assurance policies and guidelines for distance education in Australia and New Zealand. In I. S. Jung \& C. Latchem (Eds.), Quality assurance and accreditation in distance education and e-learning: Models, policies, and research, (pp. 91-101). New York: Routledge.

Sallis, E. (2002). Total quality management in education. London: Kogan Page.

Saldana, J. (2009). The coding manual for qualitative researchers. London: SAGE.

Shanahan, T. (2009). Accountability initiatives in higher education: An overview of the impetus to accountability, its expressions and implications. Accounting or accountability in higher education: Proceedings from the OCUFA Conference 2009, 3-15.

Stake, R. E. (2005). Qualitative case studies. In N. K. Denzin \& Y. S. Lincoln (Eds.), The Sage handbook of qualitative research, (pp. 443-466). Thousand Oaks, CA: Sage Publications.

UT (2010). Brief information about Universitas Terbuka Indonesia: Submitted to International Council for Open and Distance Education (ICDE) Standard Agency (ISA). Unpublished. Jakarta, ID: Universitas Terbuka.

UT (2012). Quality assurance system of Universitas Terbuka (Sistem jaminan kualitas Universitas Terbuka): JKUM UTO0. Unpublished. Jakarta, ID: Universitas Terbuka.

UT (2015). Universitas Terbuka's self evaluation report 2015. Submitted to International Council for Open and Distance Education (ICDE). Unpublished. Jakarta, ID: Universitas Terbuka.

UT (2016). Rector UT yearly report as of 2015 (Laporan kerja tahunan Rektor UT 2015). Unpublished. Jakarta, ID: Universitas Terbuka.

Vlasceanu, L., Grunberg, L., \& Parlea, D. (2007). Quality assurance and accreditation: A glossary of basic terms and definitions. Bucharest, RO: UNESCO-CEPES.

Warren, J., McManus, J., \& Nnazor, R. (1994). Quality assurance and distance education: A review of the literature. In P. M. Deshpande \& I. Mugridge (Eds.), Perspectives on distance education: Quality assurance in higher education, (pp. 1-20). Vancouver, BC: The Commonwealth of Learning. 